\title{
Curtain color and lighting program in broiler production: III - thermal comfort
}

\author{
Paulo Giovanni de Abreu ${ }^{1}$, Valéria Maria Nascimento Abreu ${ }^{1}$, Arlei Coldebella ${ }^{1}$, Fátima \\ Regina Ferreira Jaenisch ${ }^{1}$, Doralice Pedroso de Paiva ${ }^{1}$
}

\author{
${ }^{1}$ Embrapa Suínos e Aves, Br 153, Km 110, Caixa Postal 21 - 89700-000, Concórdia, Santa Catarina, Brasil.
}

ABSTRACT - The objective of this study was to evaluate the thermal comfort of broilers reared under two lighting programs (almost continuous and intermittent) in broiler houses with yellow or blue lateral curtains. The experiment was carried out from June 24, 2004 until May 12, 2005. Six consecutive flocks were housed in four $12 \times 10 \mathrm{~m}$ broilers houses internally divided into four pens of 200 birds each. Six flocks were raised on the same litter. The registration of data was accomplished at 3-hour intervals, for 24 hours twice a week. In the center of each pen and outside the house, dry and wet bulb temperatures, black globe temperature, and air velocity were collected. Based on the data collected at each time, air temperature (AT) $\left({ }^{\circ} \mathrm{C}\right)$, black globe humidity temperature index (BGHTI), radiant thermal load (RTL) (W/m²), and relative air humidity (RH) were determined. Harmonic analysis was used to estimate $\mathrm{m}, \mathrm{R}$, and $\mathrm{f}$ parameters. In general, the best results in terms of thermal comfort for the birds were found when near-continuous lighting program and yellow curtain were used.

Key Words: animal environment, poultry house, thermal index

\section{Introduction}

The "optimal climate", which does not require any adjustment to provide thermal comfort for poultry reared indoors, does not exist in Brazil. In every Brazilian region, the climate factor needs to be corrected to provide favorable environmental conditions to birds. Heat, cold, and daily temperature variation (thermal range) are the weather factors that most affect poultry behavior, performance, and disease resistance. When internal poultry house conditions are adequate, birds respond with high weight gain and feed intake, low feed conversion ratio and low mortality. In addition, as described by Perdomo (1998), energy costs (gas, wood, and electricity) to heat and/or cool the environment are reduced. According to that author, it is necessary to store heat to protect broilers under 28 days from "environmental chilling" during the night in every month of the year. One solution is to prevent the loss of heat generated inside the poultry house to the outside, saving heating costs. The use of side curtains to control ventilation and a drop ceiling (both made of waterproof material) are sufficient to reduce internal heat losses.

The placement of curtains outside the sides of poultry houses aims to prevent the entrance of sun rays and rain inside the poultry house and to control lightness and ventilation inside the house. Curtains made of different fibers, porous, of special plastic mesh or canvas allow gas exchange with the outside, and only work as wind shields, and are not capable of providing insulation (Abreu \& Abreu, 2001a).

In commercial broiler production, yellow curtains are commonly used; however, blue curtains have been recommended. It should be noted that there is little scientific information on the use of blue curtains, particularly in open-sided poultry houses with automation or with air conditioning and that apply lighting programs to stimulate feed intake.

The objective of lighting programs is to regulate feed intake. Continuous photoperiods can be applied as a continuous lighting program (24 hours of light). Nearly continuous (23L:1D + 16L:8D, where $\mathrm{L}=$ hours of light; $\mathrm{D}=$ hours of darkness), and intermittent light programs are characterized by presenting repeated periods of light and darkess within 24 hours (Classen, 1996).

The proposal of the present study was based on the assumption that curtain color may provide a more or less comfortable environment to broilers, and that lighting programs may increase or reduce bird movement, consequently resulting in higher or lower heat dissipation to the environment, affecting thermal comfort. Therefore, the objective of this study was to evaluate the thermal comfort of broilers reared under two different lighting programs (nearly continuous and intermittent) in broiler houses equipped with yellow or blue curtains. 


\section{Material and Methods}

The trial was carried out at Campo Experimental de Suruvi, belonging to Embrapa Suínos e Aves, in Concórdia, Santa Catarina, Brazil, and located at $27^{\circ} 14^{\prime} 02^{\prime \prime S}$ and $52^{\circ} 01^{\prime}$ 40"W, between June 24, 2004 and May 12, 2005. Six consecutive broiler flocks were reared in four broiler houses measuring $12 \mathrm{~m} \times 10 \mathrm{~m}$, internally divided into four pens , each one housing 200 birds.

A total of 19,200 Ross males was distributed according to a completely randomized experimental design in a $6 \times 2 \times 2$ factorial arrangement (six flocks, two lighting programs and two curtain colors), with four replicates per treatment. The first flock was housed on new litter, which was reused by the subsequent flocks. Litter was replaced only in the brooding area. Light was provided by $60 \mathrm{~W}$ incandescent light bulbs. Treatments consisted of curtain color (yellow or blue) and two lighting programs (nearly continuous: 23L:1D; intermittent: 16L:2D + 1L + 2D, where $\mathrm{L}=$ hours of light and $\mathrm{D}=$ hours of darkness) distributed as follows: house 1 = blue curtain and intermittent light; house 2 = yellow curtain and intermittent light; house 3 = yellow curtain and nearly continuous light; house 4 = blue curtain and nearly continuous light.

Environmental parameters were recorded twice a week during 24 hours every three hours. A dry-bulb thermometer, a wet-bulb thermometer, and a black-globe thermometer were placed in each pen and outside the broiler houses. Air velocity was recorded using an anemometer. Based on the data recorded in the internal and external environment, air temperature $\left(\mathrm{AT},{ }^{\circ} \mathrm{C}\right)$, wet bulb globe temperature (WBGT), radiant heat load (RHL, $\mathrm{W} / \mathrm{m}^{2}$ ), and relative air humidity (RH, \%) were determined. Internal environment was evaluated using harmonic analysis, according to Morettin \& Toloi (2004), by applying the model $(1): \mathrm{y}_{\mathrm{t}}=\mu+\mathrm{R} \cos (\omega \mathrm{t}+\phi)+\varepsilon_{\mathrm{t}}$, in which: $\mathrm{y}_{\mathrm{t}}=$ observed value of the parameters in time $\mathrm{t} ; \mu=$ mean; $\mathrm{R}=$ range; $\phi=$ phase angle; $\omega=$ frequency, in this case fixed as $\pi / 12$, and $\varepsilon_{t}=$ random component. In order to evaluate the effect of lighting programs and curtain color on parameters $\mu$, $\mathrm{R}$ and $\phi$, their estimates were calculated for each combination of treatment, flock, week and pen. Based on these estimates, the effects of flock, curtain color, lighting program, week and the interactions of the last three factors on parameters $\mu, \mathrm{R}$ and $\phi$ were evaluated through the theory of mixed models for repeated measures and 15 types of variance and covariance matrix, applying PROC MIXED of SAS statistical package (SAS Institute Inc, 2003), as described by Xavier (2000). The structure used in the analysis was chosen based on the lowest value of the Akaike Information Criterion (AIC). The maximum restricted likelihood was used as estimation method. Harmonic analysis was also applied to external environmental data, estimating parameters $\mu, \mathrm{R}$ and $\phi$ for each flock and week and, finally, calculating the general mean of these parameters in order to compare the curves of internal environment parameters with those of the external environment.

\section{Results and Discussion}

The main effects of flock, week and curtain color were significant $(\mathrm{P}<0.005)$ for all parameters, whereas the effect of lighting program and of the interaction curtain color $x$ lighting program were significant for air temperature, wet bulb globe temperature and radiant heat load (Table 1).

The details of the interaction curtain $\times$ light show that there was no effect of curtain colon on air temperature, wet bulb globe temperature and radiant heat load when the nearly continuous lighting program was used (Table 2). However, when the intermittent lighting program was applied, the lowest parameter values were obtained with the yellow curtain. Considering curtain color, there were no differences in those parameters when yellow curtains were used. When houses had blue curtains, the lowest values were obtained with the nearly continuous lighting program. Therefore, in general, the highest values were obtained with blue curtains and intermittent lighting program. However, air temperature was similar among the four broiler houses.

In any study on the physiological response of animals to environmental factors or on the effect of housing

Table 1 - Analysis of the intercept of air temperature, wet bulb globe temperature, radiant heat load, and relative air humidity

\begin{tabular}{|c|c|c|c|c|}
\hline Causes of variation & Air temperature & Wet bulb globe temperature & Radiant heat load & Relative humidity \\
\hline Flock & $<0.0001$ & $<0.0001$ & $<0.0001$ & $<0.0001$ \\
\hline Curtain & 0.0017 & 0.0095 & 0.0079 & 0.0071 \\
\hline Light & 0.0060 & 0.0149 & 0.0007 & 0.2898 \\
\hline Week & $<0.0001$ & $<0.0001$ & $<0.0001$ & $<0.0001$ \\
\hline Curtain $\times$ light & $<0.0001$ & 0.0039 & $<0.0001$ & 0.5404 \\
\hline Light $\times$ week & 0.3712 & 0.4932 & 0.5574 & 0.7127 \\
\hline Curtain $\times$ week & 0.9997 & 0.9947 & 0.9745 & 0.9312 \\
\hline Curtain $\times$ light $\times$ week & 0.9117 & 0.9800 & 0.8265 & 0.1779 \\
\hline
\end{tabular}


environment on animal performance, comfort, and welfare, the environment where animals are housed needs to be numerically described. In the present study, air temperature, wet bulb globe temperature, and radiant heat load were higher in the house equipped with blue curtains and using intermittent lighting program (Table 2). Relative air humidity was only influenced by curtain color, and the highest relative humidity values were obtained in houses with blue curtains (Table 2). According to Abreu \& Abreu (2001b), 60 to $70 \%$ are the optimal air relative humidity values for broilers, regardless of age, but all the values obtained in the present experiment were higher than these recommendations. Oliveira et al. (2006), when studying the effects of temperature and relative humidity on the performance and carcass cuts' yield of 1- to 49-day-old broilers, concluded that high temperature impaired the performance and carcass yield of these broilers, and these effects are more stressed when relative air humidity goes up. Furtado et al. (2003) analyzed the thermal comfort of poultry houses with different environmental conditioning systems and concluded that air temperature, wet bulb globe temperature, and radiant heat load during the hottest periods of the day reached excessive values for broilers, but relative air humidity remained within the optimal range.

As shown by the analysis of ranges (R) (Table 3 ), the main flock and week effects were significant $(\mathrm{P}<0.01)$ for all parameters, and curtain color significantly influenced $(\mathrm{P}<0.05)$ AT and relative humidity, whereas the interaction curtain $\times$ light was significant for relative humidity.

In order to maintain broiler comfort, the range of environmental parameters must be as narrow as possible. Houses with yellow curtains and intermittent lighting program provided the narrowest AT range (Table 4) and the lowest range was obtained with the intermittent lighting program and blue curtains.

On phi $(\phi)$ values, there was only flock and week effects (Table 5). Phi is the phase angle, i.e., it determines the behavior of the curve. These results show that the curves describing the behavior of temperature, WBGT, radiant heat load and relative humidity, are changed only by flock and week, which depend on weather changes and the season during which the experiment was carried out.

Table 2 - Mean values of the intercepts of air temperature, wet bulb globe temperature, radiant heat load, and relative air humidity

\begin{tabular}{|c|c|c|c|}
\hline \multirow[t]{2}{*}{ Lighting program } & \multicolumn{2}{|c|}{ Curtain color } & \multirow[b]{2}{*}{ Mean } \\
\hline & Yellow & Blue & \\
\hline \multicolumn{4}{|l|}{ Air temperature $\left({ }^{\circ} \mathrm{C}\right)$} \\
\hline Intermittent & $19.88 \pm 0.17 \mathrm{bA}$ & $21.13 \pm 0.17 \mathrm{aA}$ & $20.50 \pm 0.12$ \\
\hline Mean & $19.99 \pm 0.12$ & $20.54 \pm 0.12$ & \\
\hline \multicolumn{4}{|c|}{ Wet bulb globe temperature } \\
\hline Mean & $69.06 \pm 0.21$ & $69.85 \pm 0.21$ & \\
\hline \multicolumn{4}{|c|}{ Radiant heat load $\left(\mathrm{W} / \mathrm{m}^{2}\right)$} \\
\hline Nearly continuous & $431.87 \pm 0.86 \mathrm{aA}$ & $430.41 \pm 0.86 \mathrm{aB}$ & $431.14 \pm 0.61$ \\
\hline Intermittent & $431.09 \pm 0.86 \mathrm{bA}$ & $437.23 \pm 0.86 \mathrm{aA}$ & $434.16 \pm 0.61$ \\
\hline Mean & $431.48 \pm 0.61$ & $433.82 \pm 0.61$ & \\
\hline \multicolumn{4}{|c|}{ Relative air humidity (\%) } \\
\hline
\end{tabular}

Means followed by different small letters in the same row and different capital letters in the same column are different (P $\leq 0.05)$ by the $\mathrm{F}$ test.

Table 3 - Analysis of air temperature, wet bulb globe temperature, radiant heat load and air relative humidity ranges

\begin{tabular}{|c|c|c|c|c|}
\hline Causes of variation & Air temperature & Wet bulb globe temperature & Radiant heat load & Relative humidity \\
\hline Flock & $<0.0001$ & $<0.0001$ & $<0.0001$ & $<0.0001$ \\
\hline Curtain & 0.0092 & 0.0724 & 0.3338 & 0.0150 \\
\hline Light & 0.0019 & 0.5611 & 0.7258 & 0.1165 \\
\hline Curtain $\times$ light & 0.0947 & 0.2392 & 0.4873 & 0.0500 \\
\hline Light $\times$ week & 0.9127 & 0.4296 & 0.7961 & 0.4861 \\
\hline Curtain $\times$ week & 0.9336 & 0.8846 & 0.9571 & 0.8682 \\
\hline
\end{tabular}

Non-structure variance and covariance matrix structures were used. 
Table 4 - Mean range values of air temperature, wet bulb globe temperature, radiant heat load, relative air humidity

Lighting program Curtain color

\begin{tabular}{|c|c|c|}
\hline Yellow & Blue & Mean \\
\hline $4.43 \pm 0.08$ & $4.51 \pm 0.08$ & $4.47 \pm 0.06 \mathrm{~A}$ \\
\hline $4.05 \pm 0.08$ & $4.39 \pm 0.08$ & $4.22 \pm 0.06 \mathrm{~B}$ \\
\hline $4.24 \pm 0.06 b$ & $4.45 \pm 0.06 a$ & \\
\hline $4.93 \pm 0.20$ & $5.06 \pm 0.20$ & $4.99 \pm 0.14$ \\
\hline $4.59 \pm 0.20$ & $5.18 \pm 0.20$ & $4.88 \pm 0.14$ \\
\hline $4.76 \pm 0.14$ & $5.12 \pm 0.14$ & \\
\hline $26.22 \pm 1.02$ & $26.50 \pm 1.02$ & $26.36 \pm 0.72$ \\
\hline $25.16 \pm 1.02$ & $26.85 \pm 1.02$ & $26.01 \pm 0.72$ \\
\hline $25.69 \pm 0.72$ & $26.68 \pm 0.72$ & \\
\hline $12.49 \pm 0.53 \mathrm{aA}$ & $12.21 \pm 0.53 \mathrm{aA}$ & $12.35 \pm 0.37$ \\
\hline $12.69 \pm 0.53 \mathrm{aA}$ & $10.33 \pm 0.53 \mathrm{bB}$ & $11.51 \pm 0.37$ \\
\hline $12.59 \pm 0.37$ & $11.27 \pm 0.37$ & \\
\hline
\end{tabular}

Air temperature $\left({ }^{\circ} \mathrm{C}\right)$

Nearly continuous

Intermittent

Mean

$11.27+0.37$

Wet bulb globe temperature

Nearly continuous

Intermittent

Mean

$12.59 \pm 0.37$

$4.51 \pm 0.08$

$4.39 \pm 0.08$

$5.06 \pm 0.20$

$5.18 \pm 0.20$

Radiant heat load $\left(\mathrm{W} / \mathrm{m}^{2}\right)$

Nearly continuous

Intermittent

Mean

Relative air humidity (\%)

Nearly continuous

Intermittent

Mean

$11.27 \pm 0.37$

$4.47 \pm 0.06 \mathrm{~A}$

6B

Table 5 - Summary of the phi analysis for air temperature, wet bulb globe temperature, radiant heat load and relative air humidity

\begin{tabular}{|c|c|c|c|c|}
\hline Causes of variation & Air temperature & Wet bulb globe temperature & Radiant heat load & Relative humidity \\
\hline Flock & $<0.0001$ & $<0.0001$ & $<0.0001$ & $<0.0001$ \\
\hline Curtain & 0.9808 & 0.5537 & 0.6854 & 0.2353 \\
\hline Light & 0.0629 & 0.8208 & 0.4465 & 0.0666 \\
\hline Week & $<0.0001$ & $<0.0001$ & $<0.0001$ & $<0.0001$ \\
\hline Curtain $\times$ light & 0.4101 & 0.6440 & 0.4600 & 0.5050 \\
\hline Light $\times$ week & 0.5501 & 0.5734 & 0.5121 & 0.0782 \\
\hline Curtain $\times$ week & 0.7440 & 0.6591 & 0.3443 & 0.8804 \\
\hline Curtain $\times$ light $\times$ week & 0.3846 & 0.6849 & 0.5809 & 0.4909 \\
\hline
\end{tabular}
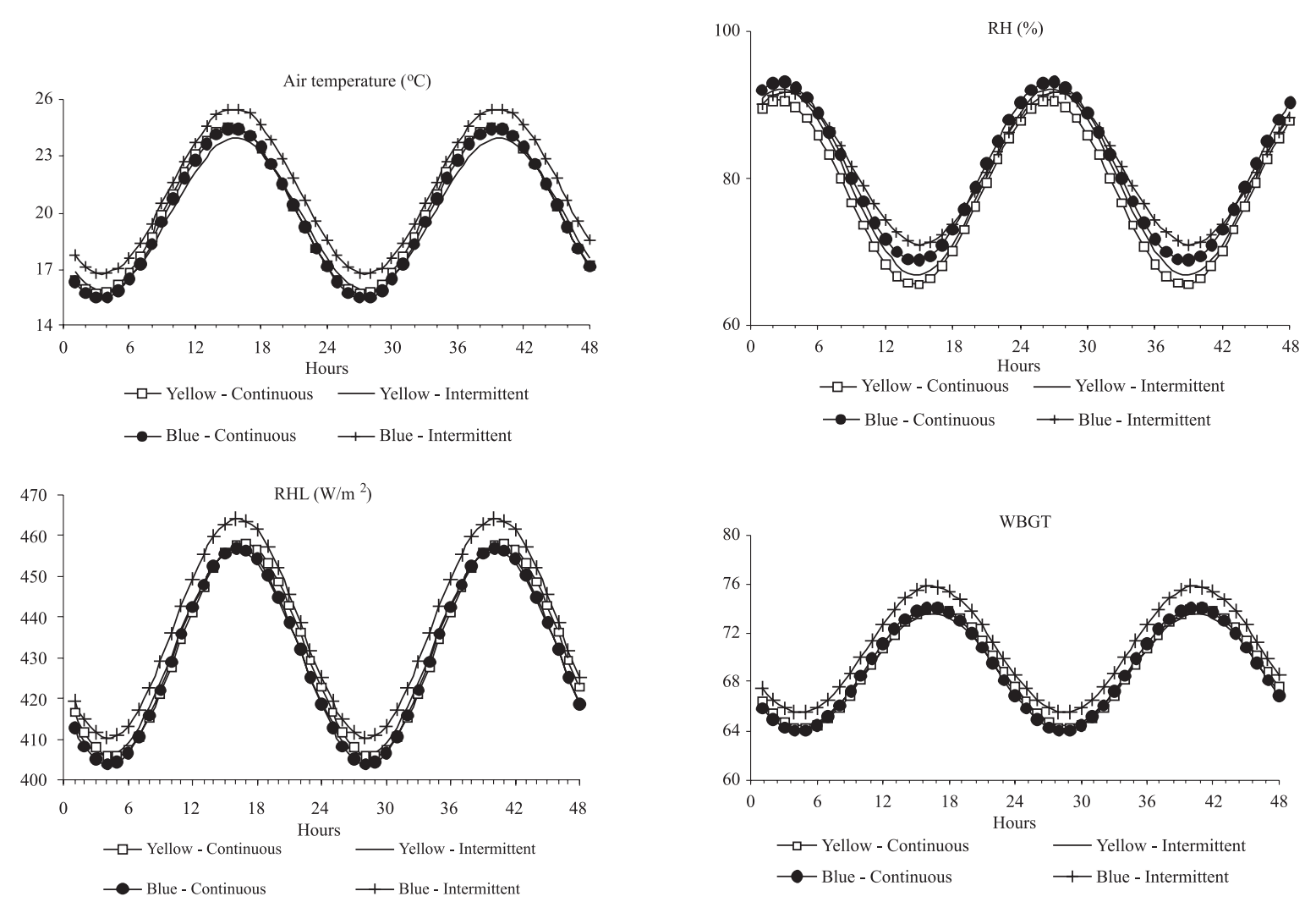

Figure 1 - Air temperature, WBGT, radiant heat load and relative humidity during the experiment. 
Mean phi values (Figure 1) demonstrate that the slope angle is similar among lighting programs and curtain colors. Those values also describe the opposite behavior of air relative humidity when compared to the other parameters, that is, when AT, WBGT and radiant heat load increased during the day, air relative humidity decreased.

Minimal AT, WBGT and radiant heat load values were recorded around 2 a.m. and maximal values at 2 p.m., contrarily to the relative humidity data observed. The behavior of the external environment parameters is similar to those of the internal environment (Figure 2, Table 6).

As expected, the internal environmental conditions were more favorable to the broilers. Air temperature, wet bulb globe temperature, radiant heat load and relative air humidity values corresponding to the treatments followed the same cyclic trends as the external parameters, as shown by the parameter means (intercept values) and narrower range of these parameters inside the broiler house.

Table 6 - Mean intercept, range, phi and maximum and minimum points of external environmental parameters

\begin{tabular}{lcccc}
\hline Parameter & Intercept $(\mu)$ & Range $(\mathrm{R})$ & Phi $(\phi)$ & max. T \\
\hline A T & 20.57 & 7.08 & 2.45 & $03: 00$ \\
WBGT & 71.87 & 14.44 & 2.66 & $02: 00$ \\
RHL & 495.05 & 157.25 & 2.60 & $14: 00$ \\
RH & 81.65 & 16.53 & -0.73 & $14: 00$ \\
\hline
\end{tabular}
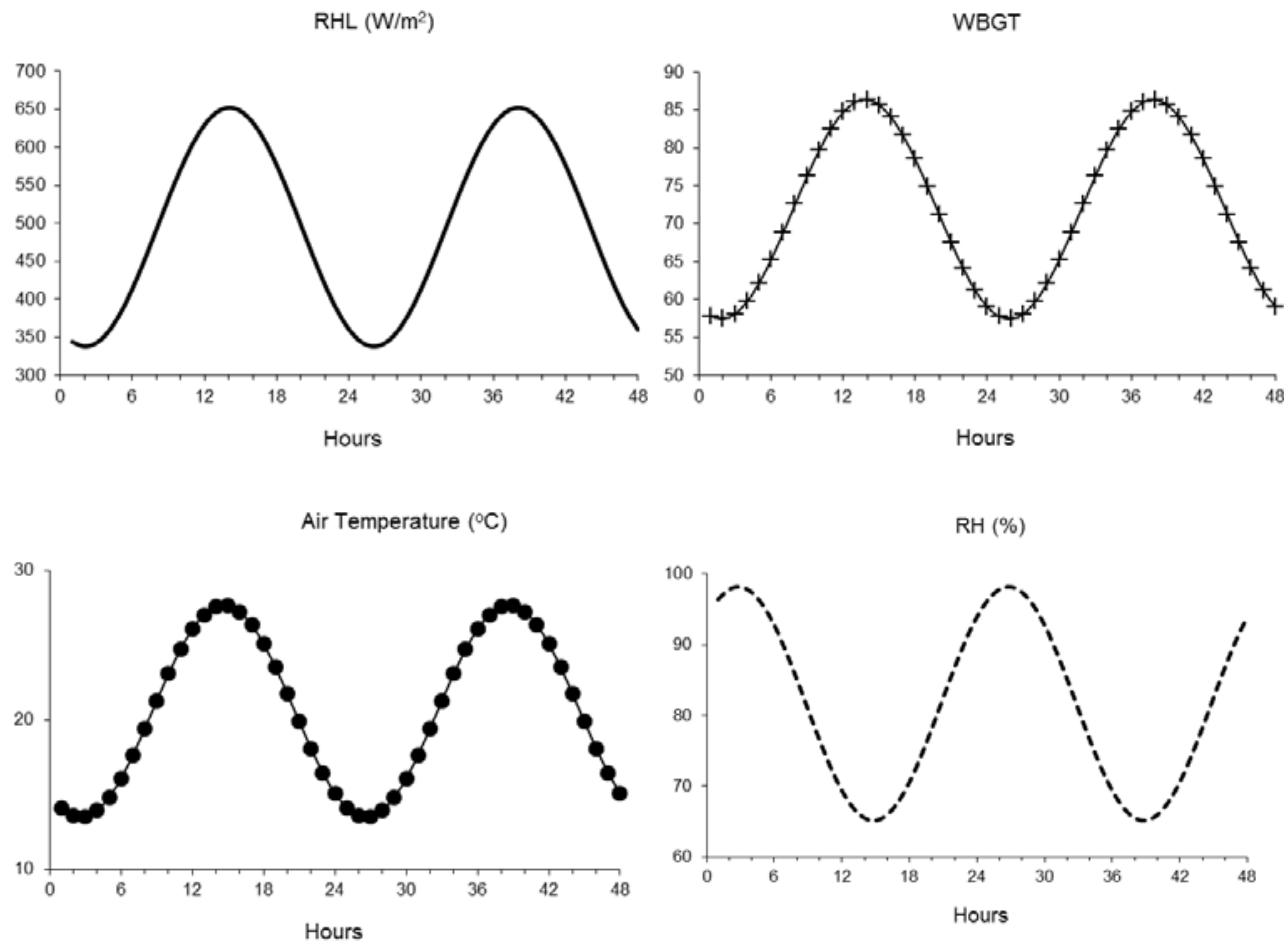

Figure 2 - External air temperature, WBGT, radiant heat load, and relative humidity during the experiment.

\section{Conclusions}

The best broiler thermal comfort conditions are obtained using the nearly continuous lighting program and yellow curtains.

\section{References}

ABREU, P.G.; ABREU, V.M.N. Função e manejo da cortina em aviários. Concórdia: Embrapa Suínos e Aves, 2001a. 2p. (Embrapa Suínos e Aves. Comunicado Técnico, 273).
ABREU, V.M.N.; ABREU, P.G. Diagnóstico bioclimático para produção de aves no Oeste Paranaense. In: CONGRESSO BRASILEIRO DE ENGENHARIA AGRÍCOLA - CONBEA, 30., 2001, Foz do Iguaçu. Anais... Foz do Iguaçu: SBEA, 2001 b. (CD-ROM).

CLASSEN, H.L. Principios sobre el manejo de luz em pollos de engorde. Avicultura Professional, v.14, n.2, p.21-27, 1996.

FURTADO, D.A.; AZEVEDO, P.V.; TINÔCO, I.F.F. Análise do conforto térmico em galpões avícolas com diferentes sistemas de acondicionamento. Revista Brasileira de Engenharia Agrícola e Ambiental, v.7, n.3, p.559-564, 2003.

OLIVEIRA, R.F.M.; DONZELE, J.L.; ABREU, M.L.T. et al. Efeitos da temperatura e da umidade relativa sobre o desempenho e o 
rendimento de cortes nobres de frangos de corte de 1 a 49 dias de idade. Revista Brasileira de Zootecnia, v.35, n.3, p.797-803, 2006. MORETTIN, P.A.; TOLOI, C.M.C. Análise de séries temporais. São Paulo: Edgar Blücher, 2004. 535p.

PERDOMO, C.C. Uso do pvc (viniagro) na melhoria do condicionamento ambiental de frangos de corte. Concórdia: Embrapa Suínos e Aves, 1998. 4p. (Comunicado Técnico, 227).
STATISTICAL ANALYSES SYSTEM - SAS. System for Microsoft Windows: release 9,1. Cary: 2002-2003. (CD-ROM).

XAVIER, L.H. Modelos univariado e multivariado para análise de medidas repetidas e verificação da acurácia do modelo univariado por meio de simulação. 2000. 91f Dissertação (Mestrado em Agronomia) - Escola Superior de Agricultura “Luiz de Queiroz”, Piracicaba. 